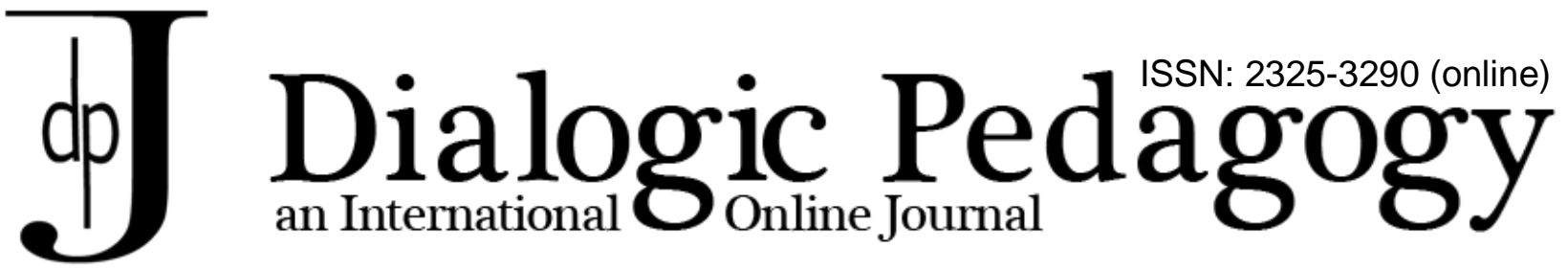

\title{
Pedagogical work of Mikhail M. Bakhtin (1920s - early 1960s) ${ }^{1}$
}

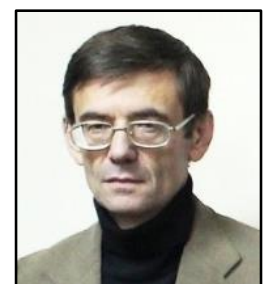

\section{Vladimir I. Laptun}

M.I. Evsevyev Mordovia State

Pedagogical Institute, Russia State

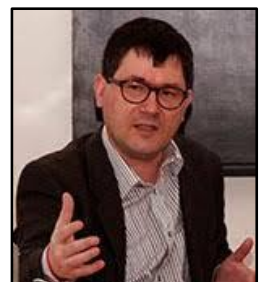

Galin Tihanov

Queen Mary University of London, UK

\begin{abstract}
The purpose of this essay to is to describe and discuss Bakhtin's pedagogical work based on diverse archival materials and memoirs of his students.

Vladimir I. Laptun, PhD., a senior lecturer of the Department of Education, M.I. Evsevyev Mordovia State Pedagogical Institute, Russia. His research interests include: life and pedagogical activity of Mikhail M. Bakhtin, history of pedagogy and education, comparative pedagogy, historical studies of local communities.

Galin Tihanov is the George Steiner Professor of Comparative Literature at Queen Mary University of London. His most recent research has been on cosmopolitanism, exile, and transnationalism. His publications include four books and nine (co)edited volumes. Tihanov is winner, with Evgeny Dobrenko, of the Efim Etkind Prize for Best Book on Russian Culture (2012), awarded for their co-edited A History of Russian Literary Theory and Criticism: The Soviet Age and Beyond (University of Pittsburgh Press, 2011). $\mathrm{He}$ is member of Academia Europaea and Honorary President of the ICLA Committee on Literary Theory. $\mathrm{He}$ is also on the Advisory Board of the Institute for World Literature (Harvard University) and is an honorary scientific advisor to the Institute of Foreign Literatures, Chinese Academy of Social Sciences. Tihanov has held visiting appointments at Yale University, St. Gallen University, University of Sao Paulo, Peking University, and Seoul National University.
\end{abstract}

$\cos \cos 80$

The life and legacy of the great Russian philosopher of the $20^{\text {th }}$ century Mikhail Bakhtin (18951975) have been analyzed in numerous studies. His collected works have been published in seven volumes; the archival documents related to his work are being published regularly. Researchers try to conceptualize and grasp all the aspects of this unique, multifaceted personality, including his work as a philosopher, literary critic, and culture expert. Besides being an outstanding scholar, Bakhtin was also a brilliant lecturer, educator, and pedagogic mentor. However, his pedagogical legacy still remains mostly unexplored.

\footnotetext{
1 Translation by Yury Almetev. We, the DPJ editors, would like to thank Caryl Emerson for directing us to this chapter. This article was translated from the original in Russian: Tihanov, G., \& Laputin, V. (2017). Pedagogical work of Mikhail M. Bakhtin (1920s - early 1960s) (Педагогическая деятельность М. М. Бахтина (1920-е - начало 1960-х годов)). Matica Srpska Journal of Slavic Studies, 92, 57-68., Novi Sad, Serbia
} 
Only a few relatively small studies touching upon certain aspects of M. M. Bakhtin's pedagogy have been published by the present moment (Plehankova, 1989; Laptun, 1992; Vasilyev, 1996). However, Bakhtin's pedagogical work was extremely multifaceted and covered many different levels. In different periods of his life, he was a school teacher, university professor, lecturer at various non-academic venues, and an academic advisor of doctoral students.

Unfortunately, not much is known about Bakhtin's pedagogical work before his arrival in Saransk in the autumn of 1936. We know that he began teaching in Nevel, a small town in Vitebsk Gubernia (now Pskov Oblast), where he had moved from Petrograd ${ }^{2}$ in early summer of 1918 . In Nevel, Bakhtin was hired to work in the Nevel Unified Professional School of the $2^{\text {nd }}$ Level as a teacher of History, Sociology, and the Russian language. During the same period, he taught in the local Pedagogical Seminary (Konkin \& Konkina, 1993, p. 53).

While in Nevel, Mikhail Mikhailovich not only worked as a teacher but also participated in social and cultural activities. He was an active participant in various debates; he gave lectures on philosophy for the local "intelligentsia"; he made public speeches before the general public. Bakhtin's brilliance as a lecturer and his profound knowledge of humanities could not but attract the attention of the local authorities of Public Education.

Thus, in September of 1919 , he received a special order to deliver a course of lectures on the History of Literature for the Arts workers (Molot, 09.29.1919, p. 2). In December of the same year, the local newspaper Molot published the following advertisement: "A free-of-charge course of lectures on Literature and Arts will soon be given by M. M. Bakhtin in Nevel. Citizens of both genders, 14 years of age and older, are welcome to participate (literacy is required)" (Molot, 06.09.1919, p. 2). In addition, in June of 1920, Bakhtin gave a course of lectures on the Russian language for the members of the Union of Workers of Public Education and Socialist Culture (Molot, 06.09.1920, p. 2).

In the autumn of 1920, M. Bakhtin moved to Vitebsk, where he had more opportunities for pedagogical work. In the early 1920s, the town featured a Pedagogical Institute, a Higher Institute of Public Education, a "Proletarian University," a conservatory, and also a number of public schools. Thanks to the assistance of his friend from Nevel, V. N. Voloshinov, who was currently working in the local bureau of people's education, Mikhail Mikhailovich was hired in October of 1920 to work in the Vitebsk State Pedagogical Institute as a professor of General Literature. Later, in December of the same year, he was hired by the Vitebsk Public Conservatory as a professor of the history and philosophy of music (Konkin \& Konkina, 1993, p. 63).

In addition to that, Bakhtin mentioned in his autobiography that he used to give lectures in the Higher Institute of Public Education, in a local Soviet Party School of the $2^{\text {nd }}$ level, and in the Political Department of the $5^{\text {th }}$ Vitebsk Infantry Division (AMSU, f. 2, op. 1, d. 54: I. 3) . $^{3}$.

Due to certain circumstances, it was only 12 years later that M. M. Bakhtin returned to active pedagogical work. In autumn of 1936, Mikhail Mikhailovich and his wife moved to Saransk, where he was offered the job of a professor of General Literature and Methods of Literature Teaching in the Literature Department (Bakhtin, 1944, p. 4).

The brief but very eventful period of Bakhtin's employment in the Mordovian Pedagogical Institute (from 1957 the Mordovian State University) has been quite thoroughly studied by researchers (e.g., Laptun,

${ }^{2}$ Now Saint Petersburg.

3 f. stands for 'fond' [foundation], d. for 'delo' [case], t. for 'tome' [volume], I. for 'list' [sheet]. 
1996, 2010). That is why we will not analyze it here in detail. Instead, we will quote an excerpt from the memoirs written by Bakhtin's students, describing him as a teacher:

He was of a small stature, slightly stooped, bald and pale, but some unforgettable brilliance was shining in his dark, intelligent eyes. His suit was almost white. During his lectures he used to hold his right hand in a pocket of his jacket, and his left under the lapel, on his chest. He never had any pieces of paper or books in his hands. Slowly perambulating around the classroom, Mikhail Mikhailovich would now retreat from the students, now approach them again. I remember that when he was speaking about Homer, analyzing his epic poems, we were amazed by his knowledge of the subject - he could recite whole chapters by heart. At such moments, we had a feeling that it was not our professor, M. M. Bakhtin, standing in front of us, but a person from Ancient Greece, who had witnessed those remote events himself and now came to share them with us. The students were listening breathlessly, as if spellbound (Nazarova-Svisheva, 1990, p. 4).

At the same time, it must be mentioned that, as much as his students were impressed with Bakhtin's lectures, some of his colleagues were of a different opinion. For instance, N. I. Abushaev, a philosophy professor, visited one of Bakhtin's lectures as part of the inspection of the Literature Department and made an emphatic conclusion: "The methods of delivery were sub-standard for a university lecture - the lecturer was dictating during the lecture" (CSARM, Fr-546, op. 1, d. 64: I. 42-42 ob.). Mikhail Mikhailovich did not agree with such evaluation of his lecture and tried to explain to the member of the City Committee of the Communist Party that "one should not evaluate methodology based on a single lecture, as a lecture is part of the whole course."

However, it was next to impossible to prove your point before such "[pedagogical] methodologists" in those days. That was perhaps the reason why many years later, remembering his first arrival in Saransk, Bakhtin noted that it had been boring to teach there as "the students were rather ignorant, and the professors were ignorant too" (Bakhtin \& Duvakin, 2002, p. 237).

At the end of 1936 - beginning of 1937, a very unwholesome atmosphere permeated the Mordovian Pedagogical Institute, which was common for the country at large at that point. That is why, in the beginning of July, 1937, Mikhail Mikhailovich and his wife had to leave Saransk and stay temporarily with their friends in Moscow. At the end of July - beginning of August, they were in Leningrad ${ }^{4}$, and later, in August, they even managed to make a trip to Kustanai. After this, up until the end of October, the Bakhtins were oscillating between Moscow and Leningrad, hoping to settle down in one of the capitals ${ }^{5}$ and find employment there. However, Bakhtin's status of a "former exile" 6 did not allow them to do so. It was only at the end of October, that Bakhtin's friends managed to find a residence for him and his wife not far from Moscow, in Savyolovo ${ }^{7}$. That marked the start of one of the most difficult, yet at the same time productive, periods of Bakhtin's life - the so called "Savyolovo period".

It so happened that the Bakhtins spent the entire year of 1938 in Savyolovo. There was a serious reason for that. In January, Mikhail Mikhailovich suffered from an acute exacerbation of his chronic disease, which caused serious problems with his right leg. Amputation was the only solution in that situation. The surgery was successfully performed on February 17 . During the long convalescence period Bakhtin had to stay at home, that allowed him to focus on his research. Apparently, it was during that period that Bakhtin

\footnotetext{
${ }^{4}$ Now Saint Petersburg.

${ }^{5}$ I.e., Moscow or Leningrad (St. Petersburg) were interchangeable capitals in Russian/Soviet history.

${ }^{6}$ Bakhtin was arrested in 1929 by the Soviet secret police for participation in a religious philosophical organization and exiled to Kazakhstan 1929-1936.

${ }^{7}$ Savyolovo is a district of the town of Kimry in Tver Oblast. The town of Kimry is located $130 \mathrm{~km}$ from Moscow and is a district center of Tver Oblast.
} 
firmly resolved to finish his work on Rabelais, which he had initiated during his stay in Kustanai. As we know, M. M. Bakhtin completed the first version of his fundamental work Rabelais in the History of Realism in 1940.

Undoubtedly, "Rabelais" was not the only work completed by Bakhtin during his "Savyolovo period". As already mentioned above, that period was quite productive for Mikhail Mikhailovich. Many of the texts created by him in Savyolovo, however, were either first drafts or tentative sketches. Some of them were not even entitled by the author. Instead of enumerating all Bakhtin's works of that period and elaborating on them, we will mention on one of them here, entitled The Questions of Stylistics in the Russian Language Classrooms of Secondary Schools (Bakhtin, 1994). This pedagogical article was apparently written in the spring - summer of 1945, during Bakhtin's employment as a teacher at two schools - School № 39 of the Railway Department (Savyolovo, Tver Oblast) and Secondary School № 14 (Kimry), in which he worked from 1942 to $1945^{8}$.

Unfortunately, it does not seem feasible to establish the exact date of Bakhtin's employment in the school of village llyinskoye. It is only known that he taught German there and was dismissed on November 15, 1941, "due to the cuts of teaching hours" (Korkunov, 2013). It appears that he had worked for only two and a half months at that school. This fact is not surprising in itself, as the war was on and everything was changing at a dizzying speed. It is much more surprising that Bakhtin had become employed in the school that was located $15 \mathrm{~km}$ away from his residence (Korkunov, 2013). It should be mentioned that by that time his leg had been amputated and he had to use crutches.

Mikhail Mikhailovich did not stay unemployed for long. Very soon, in December of 1941 he was hired to teach at Secondary School № 39 of Yaroslavl Railway Department (in some sources it is referred to as "Railway School № 39"). Bakhtin's personal file contains "The reference of Bakhtin Mikhail Mikhailovich, a teacher of School № 39 of Yaroslavl Railway Department”. From this reference we find out that Bakhtin worked at that school as a teacher of Russian, Literature, and German from December 15, 1941, to September 20, 1945. This is how he was described in the reference:

During the four years of his work at the school, M. M. Bakhtin has proved to be a highly cultured teacher, experienced methodologist of education, and an active citizen. As an experienced worker of higher education, M. M. Bakhtin's education far exceeds the level of a secondary school teacher, which allowed him to teach his courses at a very high level and, at the same time, to help the school with various methodological questions, raising the level of cultural and professional education of the school teachers, and contributing to the school's extracurricular activities.

For four years M. M. Bakhtin conducted a teachers' workshop aimed at further development of teachers' knowledge of the Russian language and stylistics; he was the head of the school's literary workshop, which work he greatly improved; he gave lectures and presentations on methodological and literary topics, and tirelessly helped the school's young teachers as a mentor.

M. M. Bakhtin also conducted cultural and educational work, giving lectures and presentations outside the school. In his pedagogical work, M. M. Bakhtin treated his students with great respect and sensitivity, combining a high demand for students' knowledge of the subject with rearing them in the spirit of Soviet patriotism and the ideas of Marxism-Leninism.

\footnotetext{
${ }^{8}$ See also Bakhtin, 1997, pp. 511-512. During the WWII the Bakhtins lived in Savyolovo and Mikhail Mikhailovich taught at local schools. Later, he would write in his autobiography: "Since autumn of 1941 I have worked as a teacher of the secondary school in village llyinskoye (Kimry district), then Secondary School № 14 and "Railway" School № 39 in Kimry" ("Bakhtin's Personal File").
} 
As a pedagogical worker, M. M. Bakhtin can be described as a dedicated and highly disciplined professional, who is punctual and highly efficient in attending to his duties and pro-active in his work (The Archive of the Mordovian State University, f. 2. op. 1, d. 54, I. 23).

About a month after being hired to the School of the Railway Department, Bakhtin found employment at another educational establishment - Secondary School № 14 (Korkunov, 2013). At different times, he taught Russian, Literature, German, and even History at that school.

Apart from this reference, the information on Bakhtin as a school teacher is rather scant. The reference itself, being an official document, lacks any emotional descriptions. Much more informative can be the memories of former students of School № 14 about their one-legged teacher, who had been telling them about literature with such pathos. One of those students was Galina Ivanovna Mozzhuhina, who was an eighth grader in 1944/45. Many years later she tried to recreate the image of her Russian and Literature teacher in her memory:

I do not want to claim it for sure that it was M. M. Bakhtin who influenced me in my decision to also become a teacher of Russian and Literature, but recollecting the literature classes in high school, it is his lessons that come to mind. [...] He was very cautious when talking to someone. He did not socialize with other teachers, and the latter did not make any attempts to befriend him. I know for sure that only one teacher was his friend - Mikhail Vladimirovich Lebedev. When Bakhtin was leaving, he gifted many of his books to Lebedev. [...] During lessons, Bakhtin did not focus on the whole class. He did not insist that every student should listen to him (as other teachers did) - instead, he was speaking to those who were interested. At the same time, he was strict about the classroom discipline and very rigorous in terms of our studies. [...] Mikhail Mikhailovich was not very popular among the students of our class. He was very demanding but many of us were simply hungry and to study was hard. It was the war time. We, students, had to bring coal to school, to get the school heated. It was a very difficult time. Once, the students of my class decided to "sabotage" his lesson and were behaving badly. He could not bear it and left the classroom. The school principal called the parents and there were repercussions. But we never did that again. [...] So, the class was not particularly fond of Bakhtin. Many students were struggling with their studies and Bakhtin's standards were very high. Also, he was unpopular because of his strictness. Although, more capable and successful students were on good terms with him. For example, some boys from the tenth grade became friends with him. Well, the following school year he left our school and I realized what a great teacher we had lost. Another teacher was appointed to teach us and he was simply boring. Mikhail Mikhailovich was a teacher who could inspire us (Korkunov, 2013; also Ponomaryova \& Stroganov, 1992).

To make our memory picture more vivid, we have added the reminiscences of two more students of Bakhtin - Maria Isayevna Krylova, whose classroom teacher Bakhtin was in 1943 - 1944, and Valentina Georgiyevna Rak, a tenth grade student in 1944.

\section{I. Krylova:}

He organized a literary extracurricular circle. We could not have enough of his lessons, so our whole class attended that circle. [...] He could recite Goethe and Shakespeare by heart. It was exciting to listen to him, and sometimes he seemed grateful to us for listening to him (Ponomaryova \& Stroganov, 1992, p. 147).

V. G. Rak: 
He was just as hungry and cold in our school as we all were. But as soon as a lesson started, he would become oblivious to all the hardships. He was speaking to us elatedly, wildly gesticulating, and always ridiculing our school textbooks, "How can you read them? - he would ask us. - You need to read the artwork itself, the original artwork, from beginning to end!" And we were sitting there openmouthed, listening to him, oblivious to the fact that the bell had rung a long time ago (ibid., p. 148).

The memories of Bakhtin's former students cited above suggest that he was conscientious in attending his teacher's duties. He had rigorous standards for himself and his students; he genuinely tried to instill in them the love of literature; and along with them, he was patiently enduring all the hardships of the war years. At the same time, Mikhail Mikhailovich had almost no social interactions with his colleagues, except for M. V. Lebedev, mentioned above. For example, one of Bakhtin's colleagues, Maria Vasilyevna Vantsova, described him as follows, "He was very introverted and almost never communicated with us. I cannot say anything about his friends or even acquaintances. I did not know if he had any. Maybe he did not have friends at all" (ibid., p. 148).

So, throughout the war period, Mikhail Mikhailovich was working as a secondary school teacher in a small provincial town. Undoubtedly, such situation could not satisfy the scholar, which is why, immediately after the end of the war, Bakhtin began considering changing the place of residence. Mikhail Mikhailovich realized that to find any employment in Moscow or Leningrad for him was not possible. Therefore, he could only expect to be hired by a university in some remote province.

In summer of 1945, while visiting Moscow, Bakhtin went to the Public Commissariat of Education of RSFSR ${ }^{9}$ in the hope of getting some employment. This is how Mikhail Mikhailovich himself described it later:

So I went there in order to receive perhaps an employment at some provincial university and I found the head of the department of pedagogical institute, who used to be my dean in Saransk, Georgiy Sergeyevich Petrov. He saw me and said, "Go back to Saransk. I will write to the director and send you there immediately. Everything will be ready for you there. Saransk is the best option for you" (Besedy, p. 216).

Thus, Mikhail Mikhailovich and his wife Elena Alexandrovna returned to Saransk. On October 1, 1945, M. M. Bakhtin was appointed the Head of the Department of General Literature at the Mordovian Pedagogical Institute.

A few documents found in The Central State Archive of the Republic of Mordovia portray Bakhtin as a brilliant head of the department, sensitive and intelligent critic, talented educator, and methodologist. The following excerpts from the minutes of the department meetings (below) reflect M. M. Bakhtin's views on certain methodological aspects of university teaching. These concise and often hasty notes, in which the department secretaries documented the gist of Bakhtin's speeches addressed to his colleagues, still contain some important insights.

An excerpt from Bakhtin's speech at the Literature Department meeting, January 14, 1952 :

M. M. Bakhtin underscored that we must fight against routine in university education. There should be fewer lectures and more practical classes. The number of lectures must be reduced. If some topics are explained well in the textbook, they should just be referred to, but it is the material

${ }^{9}$ Russian Soviet Federative Socialist Republic, https://en.wikipedia.org/wiki/Russian Soviet Federative Socialist Republic 
that is not explained well, that needs to be taught. Students tend to rely on lectures, but we need to encourage their self-study. There should be more debates, discussions, conferences. [...] It should also be noted that students have poor knowledge of aesthetics and arts. We should speak about music and painting in our lectures. Colloquiums are necessary, even though they are often rejected $[\ldots]^{10}$.

From M. M. Bakhtin's speech at the Literature Department meeting, February 6, 1953 :

Students have been observed at the exams. In general, their knowledge has become deeper and they have been working more diligently than last year. But students still do not understand literary texts; they do not seem to grasp their meanings and express no real love of reading. They do not seem to have a genuine love of literature, which is the main drawback [...]

The educational value of literature is often neglected in our lectures. The lectures do not pay enough attention to the questions of language [...]

At the exams, students' responses are too abstract and commonplace; students are afraid to give concrete examples. They are totally ignorant in terms of history, of the described historical epoch. Students' overall cultural knowledge is inadequate - for example, they do not know who Mozart is, who Beethoven and Borodin are; they cannot name any painting by Repin $[\ldots]^{11}$

From M. M. Bakhtin's speech at the joined meeting of the departments of Literature, the Russian Language, and Mordovian Languages and Literature, October 29, 1953:

M. M. Bakhtin pointed out that the institute teachers need to know the Mordovian language and literature, that is why he suggested that a course of lectures on the Mordovian language and literature be offered. The main shortcoming of schools and colleges is the inability of educators to instill motivation in students towards language studies. Students should be taught to love the sound of language. Students' speech lacks a variety of intonations. For example, students lack the ability to express irony through intonation. The important role in instilling the love of language in students should belong to teachers. [...]

Students do not know how to use dictionaries. Literature teachers should point out for students those sections of a literary work that have certain merits. A lot of work needs to be done concerning orthoepy. Students make many mistakes in terms of orthoepy. [...] M. M. Bakhtin points out that, even though institutes should not teach elementary literacy to students, the fact is that many school graduates come to the institute being hardly literate. We must take some measures to improve students' literacy. ${ }^{12}$

From Bakhtin's speech at the Literature Department, February 3, 1954:

Almost all the professors' exams have been visited and observed [...] The following shortcomings have been revealed: 1) students are unable to participate in a discussion, which suggests that teachers themselves do not lead discussions but rather deliver information; 2) the

${ }^{10}$ Central State Archive of the Republic of Mordovia, Fr-546, op. 1, doc. 257. Minutes № 7 of the meeting of the Literature Department from January 14, 1952. Agenda: The discussion of the article "On Educational Work at the Institute."

${ }_{11}$ Central State Archive of the Republic of Mordovia, Fr-546, op. 1, doc. 177-178. Minutes № 11 of the meeting of the Literature Department from February 6, 1953. Agenda: Reports of the department members about their work in Semester 1.

${ }^{12}$ Central State Archive of the Republic of Mordovia, Fr-546, op. 1, doc. 202, 208. Minutes № 3 of the joined meeting of the Literature Department and the Department of Mordovian Languages and Literature from October 29, 1953. Agenda: On raising the general culture and literacy of students of the Department Of Language and Literature. 
lectures are not used enough for raising students' general level of culture; 3) students' knowledge of texts is sub-par; 4) students often talk about original literary texts, which they have not read, pretending to have read them; 5) the stylistic quality of student responses is deplorable. ${ }^{13}$

From Bakhtin's speech at the Literature Department of the Mordovian State University, January 6, 1958:

The more variety of methods we offer the better - but, most importantly, they should be practically useful. Practical classes have only educational goals. Special seminars have scientific research goals. We should strive to make special seminars more research oriented. Practical classes can use various methods - reports, methodological discussions, and especially the analysis of texts. Too little attention is paid to bibliography. It is paramount to select a topic for a special seminar and it should be as narrow as possible. We must also pose debatable questions to students. Every student should have a diary or a notebook to write down his thoughts and opinions. Reports must be done in writing, as they represent scientific research, but it is not necessary to read the written text out loud. Students must be taught how to read monographs. ${ }^{14}$

From M. M. Bakhtin's speech at the Literature Department meeting, October 15, 1958 :

During practical classes our students should be reminded that they need to acquire all the skills of practical work. Pedagogical training should be treated as internship [...] aesthetic education should be given special attention. History of Arts will be taught at secondary schools. At the university, we should prepare not only literature educators but also the promotors of a high aesthetic taste. We should teach students to keep up with all the new literary artwork being published. The educational role of literary artwork should be constantly stressed in our lectures. ${ }^{15}$

It should be noted that Mikhail Mikhailovich paid special attention to students' work with research and reference literature. He taught students how to treat such work in a right way, "When you start studying a scholarly book, you should never expect to understand it easily and quickly. Science is always complex and it can take time to understand a monograph or even a textbook: they require a significant concentration of the mind and hard mental work" (Bakhtin, 1958).

The pedagogical profile of Mikhail Mikhailovich is vividly depicted in the memoirs written by his former students and colleagues. Below is an excerpt from a short article written by student Yury Pavlov for the university magazine, in which he shared his admiration of the associate professor M. M. Bakhtin's pedagogical gift. The article was published on January 1, 1960:

With what passion, what inspiration is each and every word uttered by Mikhail Mikhailovich imbued! One is left wondering if it is the sound of a human voice or a thrilled murmur of a water current falling on the turbine blades and generating electric waves. This is the impression that each new original idea, enthusiastically pronounced by Mikhail Mikhailovich, produces on his students, enkindling in them the flame of curiosity and inspiration. After such fiery lectures one craves to understand even better and love even deeper this exciting science - philology [...] M. M. Bakhtin's

${ }^{13}$ Central State Archive of the Republic of Mordovia, Fr-546, op. 1, doc. 235. Minutes № 10 of the meeting of the Literature Department from February 3, 1954. Agenda: Reports of the department head and the department members about their work in Semester 1 of the 1953-1954 school year.

${ }^{14}$ Central State Archive of the Republic of Mordovia, Fr-2542, op. 1, doc. 24. Minutes № 4 of the meeting of the Literature Department from January 6, 1958. Agenda: Discussion of the methods of seminars and practical classes.

15 Central State Archive of the Republic of Mordovia, Fr-2542, op. 1, doc. 24. Minutes № 2 of the meeting of the Literature Department from October 15, 1958. Agenda: Discussion of N. S. Khrushchev's note "On the connection between school and life." 
exemplary erudition in the field of general literature is combined with his subtle and sensitive pedagogical tact, which can be called pedagogical art. All these features of Mikhail Mikhailovich's kind nature, along with his rare modesty, attract students and make them particularly fond of him. Students often turn to Mikhail Mikhailovich with many burning questions or ask him for advice and he always responds to them. The beginning poets and writers from our faculty, with both fear and hope, share their first literary attempts with him. Mikhail Mikhailovich would always respectfully discuss their works with them and provide some advice on how to improve them [...] (Pavlov, 1960).

After his retirement in August 1961, Mikhail Mikhailovich did not sever his ties with the university and his department. At first, he was teaching a small special course, and later he devoted himself to the preparation of research workers for the Mordovian University. Bakhtin was the official research advisor for five post-graduate students: Yury Basikhin, Vladimir Gobov, Alevtina Dialektova; Elvira Konyukhova, and Tamara Nefyodova (see also Vasilyev, 2013).

Alevtina Dialektova was one of his first post-graduate mentees. She graduated the Mordovian Pedagogical Institute in 1953 and later worked in Saransk public schools. This is what she shared in her memoirs:

I became Bakhtin's post-graduate student 10 years after my graduation from the institute. It was in 1963. We mostly met at his apartment since he had retired from the university. I had a weekly appointment with him at 8 PM, every Thursday. But I could drop by Mikhail Mikhailovich's place at any time for a consultation. At our meetings, he would appoint certain parts of my work for me to accomplish. The first thing he told me as his post-graduate student was the following, "Dissertation means science, and science cannot be fit into three years that are allotted to candidates for their dissertation defense. A dissertation takes at least 10 years of work, at the very least". As it later turned out, his words were prophetic, as I defended my dissertation in 1973, exactly 10 years later.

I believe it would be interesting for you to know about M. M. Bakhtin's methods of work with post-graduate students. First of all, he did not explicitly name the topic of the study. Instead, he would name the area, to which the topic would belong. For example, he said to me, "It will be the German enlightener Wieland, quite an under-researched writer of German enlightenment." For starters, Mikhail Mikhailovich allocated a period of time for me within which I was supposed to become so proficient in German in order to be able to read Wieland's books without a dictionary. He gave me a book entitled "The Spirit of Goethe's Time." It was a large book ${ }^{16}$, and he told me, "Well, translate this book first and then we will talk about the topic of your dissertation". Of course, I went "underground" (as Bakhtin's wife, Elena Alexandrovna, used to joke), translating that huge book, and did not come back to Mikhail Mikhailovich for over two months. Finally, I brought him my translation and Mikhail Mikhailovich rigorously checked my translation. My translation satisfied him (Laptun, 2010, p. 152).

In conclusion, the sources of data cited in this article suggest that Mikhail Mikhailovich Bakhtin was not only an outstanding scholar, but also a talented educator, a scholarly mentor, who generously shared his erudition, unorthodox ideas, and pedagogical experience with his students, doctoral candidates, and colleagues. It would be interesting to investigate the question of how Bakhtin's pedagogical activities influenced his research work and publications - but this should be discussed in another paper.

16 It was a monograph by Korff (1923), a well-known work on German literature. 


\section{References}

AMSU - Archive of the Mordovian State University, Saransk.

Bakhtin, M. M. \& Duvakin, V. D. (2002). M. M. Bakhtin: Besedy s V. D. Duvakinym. [M. M. Bakhtin: Conversations with Duvakin]. Moscow: Soglasiye.

Bakhtin, M. M. (1945). Voprosy stilistiki na urokah russkogo yazyka v sredney shkole [Questions of stylistics in the Russian language secondary school classrooms]. Russkaya Slovesnost', 2, 47$56^{17}$.

Bakhtin, M. M. (1958). Nekotorye zamechaniya [Some notes]. The Mordovian University.

Bakhtin, M. M. (1997). Sobraniye sochineniy [Collected Works]. Moscow: Russkiye Slovari.

CSARM - Central State Archive of the Republic of Mordovia, Saransk.

Konkin, S. S, \& Konkina, L. S. (1993). Mikhail Bakhtin: Stranitsy zhizni i tvorchestva. [Mikhail Bakhtin: Life and Creative Work]. Saransk. Mordovskoye Knizhnoye Izdatelstvo.

Korff, H. A. (1923). Gesit der Goethezeit: Versuch einer ideellen Entwicklung der klassisch-romantischen Literaturgeschichte. Teil 1: Sturm und Drang. Leipzig: J. J. Weber.

Korkunov, V. (2013). “Dachniye kanikuly” Mikhaila Bakhtina. [Mikhail Bakhtin's countryside holidays]. Zarubezhniye Zapiski, 22.

Laptun, V. I. (1992). M. M. Bakhtin. Vuzovskaya lektsiya po literature [M. M. Bakhtin. A University lecture about literature]. Vestnik Mordovskogo, 3, 14-15.

Laptun, V. I. (1996). Perviy priezd M. M. Bakhtina v Saransk (1936-1937) [The first visit of M.M. Bakhtin to Saransk (1936-1937)]. Nevelskiy Sbornik: Statyi, Pis'ma, Vospominaniya [Nevel collected works: Essays, letters, and memoirs]. St. Petersburg, Akropol, pp. 61-75.

Laptun, V. I. (2010). M. M. Bakhtin in the 1960s - 1970s: Saransk - Moscow (from the memories of his friends and colleagues). Strannik, 6, 147-152.

Molot: Gazeta Nevelskogo Soveta Rabochih, Krestyanskih i Krasnoarmeyskih deputatov [The newspaper of the Nevel Soviet of the representatives of Workers, Peasant, and Red Army Soldiers], 19191920.

Nazarova, P., \& Svishcheva, T. (1990). Takim on svetlym byl: Vospominaniya o M. M. Bakhtine [He was such a sunny person: Memoirs about M. M. Bakhtin]. Soviet Mordovia, 4.

Pavlov, Y. (1960). Chelovek bol'shoy dushi [A person of great soul]. The Mordovian University, 3.

Plehankova, N. N. (1989). Uroki Bakhtina [Lesson of Bakhtin]. Soviet Mordovia, 4.

Ponomaryova, E. N., \& Stroganov, M. V. (1992). O prebyvanii M. M. Bakhtina v Kalininskoy oblasti [About Bakhtin's living in Kalinin region]. In S. S. Konkin (Ed.) M. M. Bakhtin: Problemy nauchnogo naslediya [M. M. Bakhtin: The issues of scientific legacy]. Saransk, Izdatel'stvo Mordovskogo Universiteta [University of Mordva Press], pp. 146-149. Universiteta, 3, 14-15.

Vasilyev, N. L. (1996). M. M. Bakhtin as a school teacher. Dialog, Karnaval, Khronotop, 2, 73-77.

\footnotetext{
${ }^{17}$ Bakhtin, M. M. (2004). Dialogic origin and dialogic pedagogy of grammar: Stylistics in teaching Russian language in
} secondary school. Journal of Russian \& East European Psychology, 42(6), 12-49. 
Vasilyev, N. L. (2013). M. M. Bakhtin and his post-graduate students. In N. L. Vasilyev (Ed.) Mikhail Mikhailovich Bakhtin i fenomen "kruga Bakhtina". Moscow: URSS/Librokom, $29-41^{18}$.

\section{(c)) EY}

New articles in this journal are licensed under a Creative Commons Attribution 4.0 United States License.

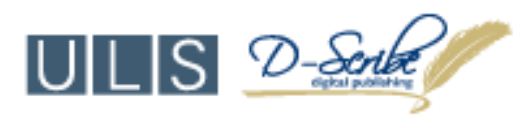

This journal is published by the University Library System, University of Pittsburgh as part of its D-Scribe Digital Publishing Program and is cosponsored by the University of Pittsburgh Press.

18 Vasiliev, N. L. (2018). M. M. Bakhtin as a university professor. Dialogic Pedagogy: An International Online Journal, 6, T1-T7, doi: 10.5195/dpj.2018.234. Retrieved from http://dpj.pitt.edu/ojs/index.php/dpj1/article/view/234/164. 